\section{Herbage Response to Precommercial Thinning in Direct-Seeded Slash Pine ${ }^{1}$}

H. E. GRELEN, L. B. WHITAKER, AND R. E. LOHREY

Range Scientist, Range Technician, and Associate Silviculturist, Southern Forest Experiment Station, Forest Service, U.S.

Department of Agriculture, Alexandria, Louisiana.

\section{Highlight}

Direct-seeded slash pines (Pinus elliottii Engelm. var elliottii) were thinned at age 3 years to densities ranging from 500 to 5,300 trees/acre. At stand age 12 years, herbage yields were inversely related to tree basal area, varying from $560 \mathrm{lb}$./acre under tree basal areas of $125 \mathrm{ft}^{2}$ to $2,230 \mathrm{lb}$. under $54 \mathrm{ft}^{2}$. Where timber stand densities were equal, yield did not vary between plots that had been thinned selectively and those on which continuous opening had been created by removing trees in strips.

An appreciable forage resource can be maintained in well-spaced slash pine plantations if proper

${ }^{1}$ Received December 31, 1971. grazing and judicious burning are practiced. When pines are regenerated by direct seeding, however, they are often so dense that they reduce forage yields drastically, even with frequent burning. Since over-dense stands also produce less than optimum amounts of timber, some land managers thin when the trees are in late seedling or early sapling stages.

In the study reported here, herbage yields at stand age 12 years were evaluated in direct-seeded slash pines that had been thinned at age 3 to densities ranging from 500 to several thousand trees/ acre. Some of the thinnings were achieved by removing all trees from strips 6.6 or $9.9 \mathrm{ft}$ in width, and on some plots a checkerboard pattern was created by running strips at right angles to each other. An opportunity was therefore afforded to compare herbage yields under such patterns of stocking 


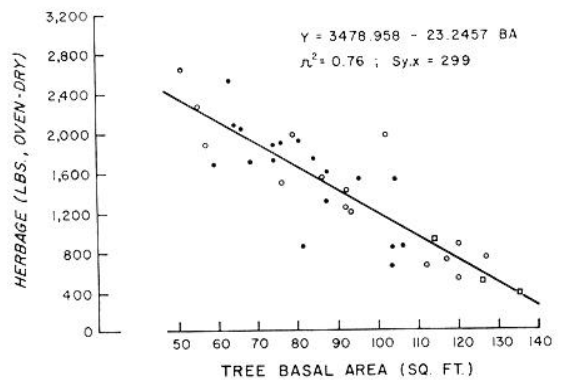

FIG. 1. Herbage yield and tree basal area/acre. Circles indicate selectively thinned plots, squares are unthinned check plots, and solid dots represent strip-thinned plots.

with yields on areas without large continuous openings.

\section{Study Area and Methods}

Slash pine seed was sown in March 1959 on 40 acres of the Palustris Experimental Forest in central Louisiana. Since the aim was to create an over-dense stand for experimental purposes, $2 \mathrm{lb}$. of seed were sown per acre-about twice the recommended rate. The catch was good, and in early 1961 stocking averaged 5,600 trees/acre. In the summer of 1961, 11 thinning treatments, plus a check, were established in three completely randomized replications on 0.4 acre plots:

Five selective thinnings, in which plots were thinned by hand to $4,200,2,800,1,400,750$, or 500 of the tallest, well-spaced healthy trees/acre.

Four strip thinnings, in which trees were cleared from strips $6.6 \mathrm{ft}$ wide, leaving swaths of trees $6.6 \mathrm{ft}$ wide. Three of these thinnings were made by hand and one by disking. Disking left 3,000 trees/acre; hand clearing 2,800. Timbered strips of two hand-cleared treatments were additionally hand-thinned to 1,400 trees/acre, one immediately after initial clearing, the other at age 5 .

1) Checkerboard: hand-cleared strips run at right angles to each other, creating 6.6$\mathrm{ft}$ square blocks averaging 1,400 trees/acre.

2) 3.3-ft strips: trees removed by hand from strips $9.9 \mathrm{ft}$ wide, leaving $3.3-\mathrm{ft}$ swaths containing 1,400 trees/acre.

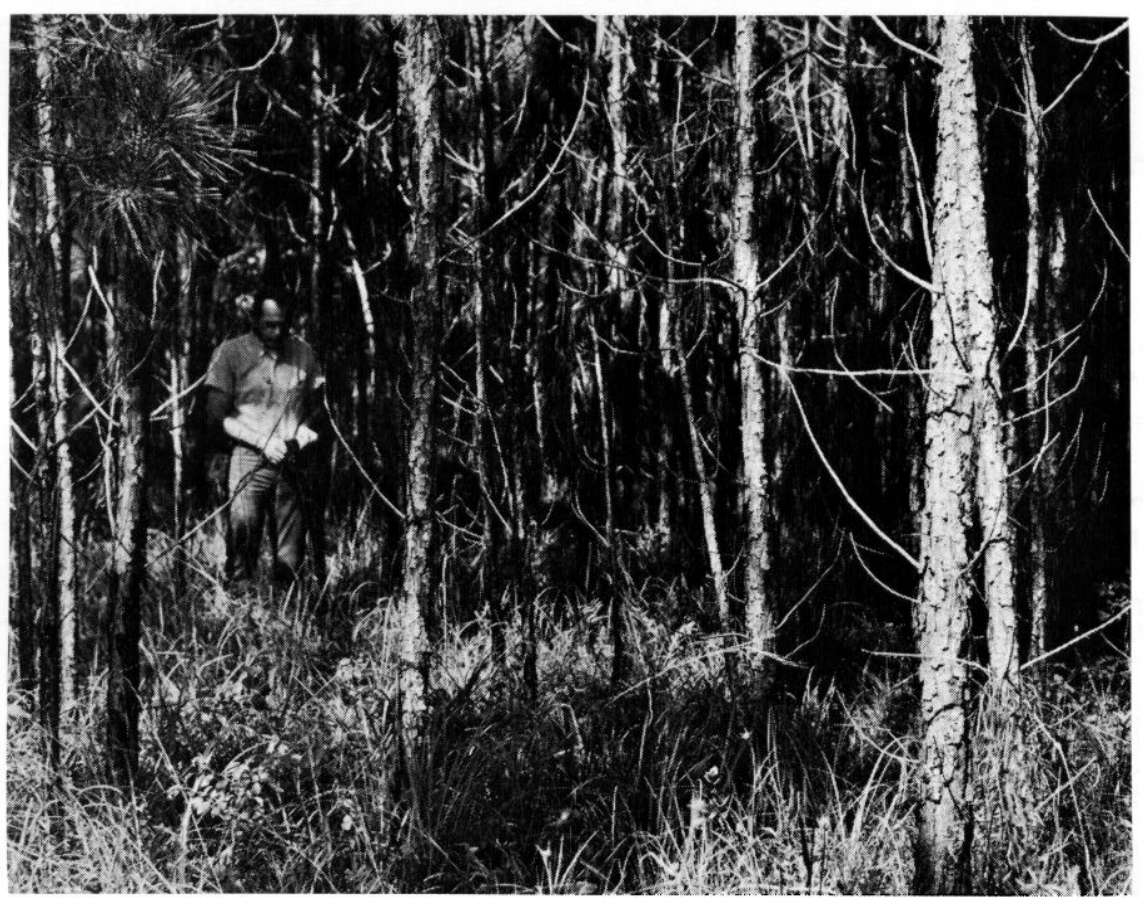

Fig. 2. Unthinned check plots, which averaged 3,737 trees/acre and $125 \mathrm{ft}^{2} /$ acre of basal area, produced $559 \mathrm{lb}$./acre herbage.

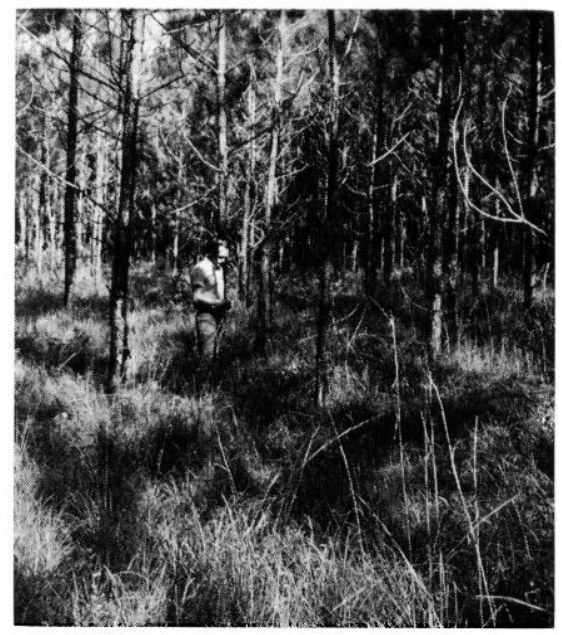

Fig. 3. Plots with 500 trees/acre averaged $54 \mathrm{ft}^{2}$ of basal area and 2,233 lb./acre oven-dry herbage.

Soils are of the Bowie and Beauregard series; surface and internal drainage are conducive to timber and herbage growth. Prescribed fires for hazard reduction were applied at ages $6,7,9$, and 11 years. The quantity of herbage was apparently enhanced by the frequent burning, which controlled hardwood sprouts and prevented smothering of forage plants by accumulated pine straw.

Trees and herbage were measured at age 12 on 0.1 -acre subplots. In each subplot herbage samples were clipped to ground level on 17 systematically spaced quadrats $1.55 \mathrm{ft}$ on edge.

\section{Results}

Herbage yields at age 12 years were least on plots with highest timber densities (Table 1). Unthinned check plots, with $125 \mathrm{ft}^{2}$ of basal area and 3,737 trees/acre, produced 559 lb./acre oven-dry herbage. Plots thinned to 500 trees/acre had $54 \mathrm{ft}^{2} /$ acre of basal area and over a ton of herbage/ acre. Yields were intermediate at timber densities between these two extremes.

The significant regression (Fig. 1) indicates that tree basal area provided a general index to herbage yield regardless of the thinning method. 
Table 1. Herbage yields (lb./acre, oven-dry) as related to density and basal area $\left(\mathrm{ft}^{2} / \mathrm{acre}\right)$ of slash pine stands.

\begin{tabular}{lccc}
\hline $\begin{array}{c}\text { Treatment and number of } \\
\text { trees left after thinning }\end{array}$ & $\begin{array}{c}\text { Trees per acre, } \\
\text { age 12 years }\end{array}$ & $\begin{array}{c}\text { Basal area } \\
\text { per acre }\end{array}$ & $\begin{array}{c}\text { Herbage } \\
\text { yield }^{9}\end{array}$ \\
\hline Check-5,600 & 3,737 & 125 & $559 \mathrm{a}$ \\
Selective-4,200 & 3,463 & 120 & $619 \mathrm{a}$ \\
6.6 strip-disk-3,000 & 2,943 & 105 & $1,040 \mathrm{ab}$ \\
Selective-2,800 & 2,607 & 113 & $1,154 \mathrm{ab}$ \\
Selective-1,400 & 1,337 & 92 & $1,266 \mathrm{abc}$ \\
6.6 strip-2,800 & 1,920 & 89 & $1,319 \mathrm{abc}$ \\
Checkerboard-1,400 & 1,047 & 71 & $1,518 \mathrm{bcd}$ \\
6.6 strip + selective-1,400 & 1,247 & 81 & $1,585 \mathrm{bcd}$ \\
6.6 strip + deferred & & & \\
selective-1,400 & 1,333 & 83 & $1,694 \mathrm{bcd}$ \\
Selective-750 & 710 & 81 & $1,699 \mathrm{bcd}$ \\
3.3 strip-1,400 & 983 & 63 & $2,049 \mathrm{~cd}$ \\
Selective-500 & 467 & 54 & $2,233 \mathrm{~d}$ \\
\hline
\end{tabular}

${ }_{1}$ Treatments are arranged in order of increasing herbage yield.

${ }^{2}$ Values with no common letter are significantly different at the 5-percent level (Duncan's multiple range test).

Pinehill bluestem (Andropogon divergens), generally a principal plant on cutover range, comprised 43 to $85 \%$ of the herbage. Percentage was greatest on heavily thinned plots with high herbage yields and least on densely timbered plots with low yields. Other bluestem grasses, including slender bluestem ( $A$. tener), which usually shares dominance with pinehill bluestem on cutover sites (Duvall, 1962), accounted for less than $10 \%$ of the herbage on most plots.

Panicums and other grasses comprised less than 20\%. The principal grasses in this group were switchgrass (Panicum virgatum), spreading panicum $(P$. rhizomatum), narrowleaf panicum ( $P$. angustifolium), and pineywoods dropseed (Sporobolus junceus).

Forbs averaged up to $40 \%$ of the herbage on the densely timbered check and selectively thinned plots, but elsewhere made up 10 to $25 \%$. Principal forbs were southern bracken (Pteridium aquilinum var. pseudocaudatum), swamp sunflower (Helianthus angustifolius), poor-joe (Diodia teres), fragrant goldenrod (Solidago odora), littleleaf tickclover (Desmodum ciliare), and weak tephrosia (Tephrosia onobrychoides). These species are found also on treeless range, and all but southern bracken, which is poisonous to cattle (Kingsbury, 1964), have forage value.

Figures 2 and 3 illustrate herbage yields under the heaviest and lightest timber stocking.

\section{Discussion}

Herbage yield was related to timber density, whether trees were uniformly distributed or crowded into strips or blocks. Though plots thinned in strips had larger continuous openings, they produced no more herbage than selectively thinned plots of comparable density. Yield differences between cleared and timbered strips within plots were not measured, but variation in herbage density appeared negligible. At 12 years, the tree canopy was fairly uniform on most plots, possibly cancelling effects of strips.

Herbage yields in these directseeded slash pine stands equalled or exceeded those in planted slash pine stands of comparable densities $^{2}$. In fact, plots with 500 trees/acre equalled the production previously reported on similar sites with no trees (Grelen and Epps, 1967). The high yields may have been related to the prescribed fires, which were applied more frequently than is common in timber management.

\section{Literature Cited}

Duvale, V. L. 1962. Burning and grazing increase herbage on slender bluestem range. J. Range Manage. 15:14-16.

Grelen, H. E., and E. A. Epps, JR. 1967. Season of burning affects herbage quality and yield on pinebluestem range. J. Range Manage. 20:31-33.

Kingsbury, J. M. 1964. Poisonous plants of the United States and Canada. Englewood Cliffs, N. J.: Prentice-Hall, Inc. $626 \mathrm{p}$.

${ }^{2}$ Wolters, G. L. Unpublished data. Southern Forest Expt. Sta., USDA Forest Service. 